\title{
Surfaces
}

\section{INTRODUCTION TO DOUGLAS J. OSLER'S "IMAGES OF LEGAL HUMANISM"}

\section{K. Ludwig Pfeiffer}

Volume 9, 2001

TROISIÈME CONGRÈS INTERNATIONAL SUR LE DISCOURS

HUMANISTE. LA RÉSISTANCE HUMANISTE AU DOGMATISME AUJOURD'HUI ET À LA FIN DU MOYEN ÂGE

THIRD INTERNATIONAL CONFERENCE ON HUMANISTIC

DISCOURSE. HUMANISTIC RESISTANCE TO DOGMATISM TODAY

AND AT THE END OF THE MIDDLE AGES

URI : https://id.erudit.org/iderudit/1065065ar

DOI : https://doi.org/10.7202/1065065ar

Aller au sommaire du numéro

Éditeur(s)

Les Presses de l’Université de Montréal

ISSN

1188-2492 (imprimé)

1200-5320 (numérique)

Découvrir la revue

Citer ce document

Pfeiffer, K. L. (2001). INTRODUCTION TO DOUGLAS J. OSLER'S "IMAGES OF

LEGAL HUMANISM". Surfaces, 9. https://doi.org/10.7202/1065065ar
Résumé de l'article

Dans le cadre du troisième congrès international sur le discours humaniste, le texte propose une introduction à " Images of Legal Humanism » de Douglas J. Osler. 


\title{
INTRODUCTION TO \\ DOUGLAS J. OSLER'S \\ «IMAGES OF LEGAL HUMANISM »
}

K. Ludwig Pfeiffer

Surfaces vol IX 101.5 (v1.0a - 15.12.01) - ISSN:

1188-2492

Tout texte reste la propriété de son auteur. Néanmoins, SURFACES demande d'être citée à l'occasion de toute autre publication du texte en question.

\begin{abstract}
In the context of the Third International

Conference on Humanistic Discourse, this text introduces Douglas J. Osler's «Images of Legal Humanism ».
\end{abstract}

\section{RÉSUMÉ}

Dans le cadre du troisième congrès international sur le discours humaniste, le texte propose une introduction à «Images of Legal Humanism » de Douglas J. Osler.

The Munich meeting viewed humanistic discourses in the perspective of a resistance to dogma. Given the connotations of dogma, this seems to invest humanistic discourses with various forms of immediately plausible values. Logically, though, the perspective is a negative one in that it does not reliably guide the selection and adoption of such values. Consequently, humanistic discourses can also be seen as generative machines producing surplus values with uncertain status. In other papers (Kablitz, Müller), it is obvious that the production of such values is hardly controllable by stopping rules, 
that therefore some form of "wild energy" (Michelet; cf. also Burckhardt) may loom threateningly behind them. There is, then, a constant oscillation between 'humane' values in a more narrow, as it were positive sense (from freedom of and for the individual to human rights), and forms of thinly veiled 'naturalisms' (that is atavisms with topical functions). The double bind of humanistic discourses lies in the commitment to human concerns, however vague, and the uncontrollable side effects sometimes main effects - these commitments produce.

Osler's paper is highly instructive in these respects. In recalling Kristeller's definition, it shows that studia humanitatis may be conceived and practised with complete neutrality to what has become in discourse history - the 'humanistic', that is the value orientation of humanism. The "model humanist" of the Renaissance, the master of languages, the cultivated polymath who combined classical learning with Christian piety (M. A. Delrio, cf. chap. III in Osler) is perfectly capable of writing a handbook on the law of witchcraft dealing in sophisticated detail with the detection, torture and execution of miscreant women. Legal humanism must then be seen as a "technical" humanism (chap. IV), that is as the historical and philological study of Roman law, indifferent or neutral with respect to the 'barbarity' Roman law and culture at large may have involved. Osler then demonstrates how the history of legal humanism, technical in its beginning, progresses step by step into a full-fledged humanism inventing values which have nothing to do with the Roman sources which they are said to be ultimately based upon (Roman law being mainly concerned with property questions, chap. V). In his studia humanitatis, the legal humanist, for a long time, is not at all interested in creating a good man, a worthy jurist, from the wholesome education purportedly provided by Latin and Greek literature (chap. VIII). It is perhaps mainly with the 18th century (and perhaps more markedly in Germany) - for reasons dealt with in other meetings of the International Conference on Humanistic Discourse (ICHD) - that a latent, and then open 'humanistification' of legal humanism sets in. Osler quotes Jugler to that effect (1755: "Legal humanism [Osler's translation; the term as such does not appear in Jugler] is the study of Roman law joined together in the tightest bond with philosophy (particularly that of the Stoics), antiquities, the Greek and Latin language, the art of textual criticism, Roman history and literature"; chap. VII). This culminates, in the 19th century, in the pathos of Theodor Mommsen extolling the "noble and liberal art of law (...), this Roman law, like a noble gold smelted again and again, today shines with a splendour 
which has not been diminished but rather augmented by age" (1870, chap. IX).

Legal humanism, as analyzed by Osler, appears as perhaps the clearest case of an a(nti)human(e), formalistic core or at least potential in what is traditionally portrayed as humanism. This might even hold true for the "philologia perennis" advocated by Gavrilov. In the intracultural frictions of the term within European legal and literary humanistic studies we may detect the prefigurement of intercultural tensions with which we are wrestling today. It does not help much, in such a situation, to redefine, with or in the wake of Habermas, humanism (e.g. classical studies) as a training in discourse skills.

Accueil Surfaces | Table des matières | Recherche Surfaces Home Page | Table of Contents | Search

PUM | Livres | Revues | Publications électroniques | Vente et distribution 